\title{
The Effectiveness of Hypnobirthing in Reducing Anxiety Level During Delivery
}

\author{
Pramita Sandy Ulya Imannura'), Uki Retno Budhiastuti²), Eti Poncorini3) \\ ${ }^{1)}$ Masters Program in Public Health, Universitas Sebelas Maret \\ 2)Departement of Obstetrics and Gynecology, Dr.Moewardi Hospital, Surakarta \\ 3)Faculty of Medicine, Universitas Sebelas Maret
}

\begin{abstract}
Background: Neonatus given birth by pregnant mothers suffering from excessive anxiety and stress have higher risk of low-birthweight, small head circumference, low APGAR score at birth, in adequate neurologyc development, premature birth, weak immunity system, and emotional disorder, than those given birth by happy mothers. This study aimed to examine the effect of effectiveness of hypnobirthing in reducing anxiety level during delivery.

Subjects and Method: This was an analytic experimental study with Randomized Control Trial (RCT) design. A sample of 30 pregnant mothers near delivery date was selected for this study and allocated into hypnobirthing group and no-hypnobirthing group. The dependent variable was anxiety during delivery. The independent variable was hypnobirthing. The anxiety level between the two groups was tested by Mann Whitney.

Results: After intervention, pregnant mothers who received hypnobirthing had anxiety level as low as $41.33(\mathrm{p}=0.003)$. Pregnant mothers who did not receive hypnobirthing had anxiety level as low as $51.60(p=0.003)$. The reduction of anxiety between the two groups was statistically significant.

Conclusion: Hypnobirthing can effectively reduce anxiety among pregnant mothers during birth delivery.
\end{abstract}

Keywords: hypnobirthing, anxiety

\section{Correspondence:}

Pramita Sandy Ulya Imannura. Masters Program in Public Health, Sebelas Maret University, Surakarta. Email: oxytocinyoga@gmail.com.

\section{BACKGROUND}

$\overline{\text { Hypnobirthing is a proven method of trying }}$ to guide and prepare women for childbirth in a calm and comfortable way. Hypnobirthing is a program that considers psychological, physical, welfare of the mother, father, newborn baby, self-empowerment, calmness while at home, calmness while in the hospital, or in the delivery room. Hypnobirthing program is about the process of childbirth education which includes breathing, relaxation, visualization of meditation practice, paying attention to nutrition and positive body toning (Madden, 2012).

Research using 10 non-pharmacological methods conducted on 46 people found that breathing, relaxation, acupressure and massage techniques were the most effective techniques in reducing labor pain (Brown et al., 2001). According to Cyna (2004), women who use hypnosis are considered to have more significant labor pain than controls, as well as showing that hypnosis reduces the use of opioids (meperiine) and increases the incidence of not requiring pharmacological analgesia in labor. The use of hypnotherapy in pregnancy and childbirth has been practiced for more than a century and is said to be one of the best useful ways of hypnosis.

Data from the World Health Organization (WHO) (2010) show that around 5\% of non-pregnant women experience anxiety, 
8-10\% during pregnancy, and increase to $13 \%$ before delivery. Many mothers do not want or lack confidence to feel labor pain, mothers give birth to assume that drugs and epidural anesthesia or by cesarean section can help relieve labor pain (Varney et al., 2007). Anxiety before childbirth in pregnant women is a physiological thing, but in facing of childbirth there will be a series of physical and psychological changes that begin from the occurrence of uterine contractions, cervical dilatation, and placental expenditure which ends with maternal and infant care. Anxiety and depression are two types of psychiatric disorders because they are interrelated (Hurlock, 1997).

Feelings of fear and anxiety in facing childbirth are the elements that can cause psychological and physical tensions, including manifestation of the muscles associated with labor. In this situation, the endocrine system will release each hormone into the bloodstream in order to prepare the body in an emergency situation. An increase in adrenaline and non-adrenaline hormones results in dysregulation of the body's bio-chemistry, so that physical tension arises in pregnant women such as an increase in heart rate, breathing rhythm, blood pressure, muscle tension (low back pain), metabolic rate, and production of stress hormones In addition, it is often heard, including tiredness, digestive problems, constipation and swelling (Fiori, 2005).

Excessive stress hormones produced in pregnant women can interfere with the blood supply to the fetus and can make the fetus hyperactive. Depression and antenatal anxiety directly impact postpartum parenting stress. Third trimester depression is $13 \%$ to $22 \%$ of postpartum stress events at three months to six months after delivery (Misri, 2010).

\section{SUBJECTS AND METHOD}

This study is an experimental analytic with completely randomized control design (RCT), RCT was used to control confounding factors, namely other factors that also influenced the research variables. This research was conducted at the Laksana Medica Sukoharjo pharmacy and RB Marga Mulya Mojosongo Surakarta. The randomization procedure allocated research subjects to the experimental and control groups (Murti, 2013).

The experimental group in this study is that there was 1 group that was given an intervention namely the group with hypnobirthing intervention. The sampling technique in this study was random, the sample used was pregnant women with a gestational age of 30-34 weeks and the research subjects were at least 30 subjects for each group. The independent variable is hypnobirthing. The dependent variable is the level of anxiety. The onfounding variables include potential stressors, maturation, education, economy, physical, personality type, environment and situation, age, threats to physical integrity, threats to self esteem.

The instrument used in this study was an anxiety level questionnaire using parametric tests because of the continuous data scale. The analysis aimed to differentiate the mean anxiety between the treatment group and the hypnobirthing control group using Mann Whitney.

\section{RESULTS}

The characteristics of research subjects included age, parity, complications, education, employment, ethnicity, ANC, and income. The subjects of this study were categorized into 2 groups, namely hypnobirthing intervention group amounting to 15 subjects and control groups amounting 
to 15 subjects. Research subjects with $<20$ years for about $6.7 \%, 20-35$ years for about $86.6 \%$ and $\geq 35$ years amounting to $6.7 \%$. In parity with primigravida, there was $63.3 \%$, whereas in multigravida, there was $36.7 \%$. There were $93.3 \%$ complications with no complications and 6.7 complications\%.

The education level of low-pregnant women (SD-SLTP) is $16.7 \%$ and the level of tertiary education (SLTA-PT) is $83.3 \%$. The employment status of pregnant women as a housewife is $33.3 \%$, while the status of pregnant women working is $66.7 \%$. All pregnant women perform ANC more than 4 times. Mothers with family income $<$ UMR are $40 \%$, and income of $\geq$ minimum wage is $60 \%$.

\section{Hypothesis Test}

The average score of research subjects who had an anxiety before joining the hypnobirthing class was 55.80. The lowest score of anxiety score before joining the hypnobirthing class was 42, while the highest score was 78. The average score of research subjects who had an anxiety after joining hypnobirthing class was 41.33. The lowest score of anxiety before joining hypnobirthing class was 35 while the highest score was 75 .

This showed a decrease in the level of anxiety before and after joining the hypno- birthing class. The decrease in anxiety scores in primigravida and multigravida pregnant women with 30-34 weeks' gestation in facing the delivery could be seen in the decrease of the average score by 14.47 , which was from the score of 55.80 to 41.33 . The decrease in anxiety scores in primigravida and multigravida pregnant women with 30-34 weeks' gestation in facing the delivery could also be seen from the lowest and highest score ranges ranging from 42 and 78 before joining a hypnobirthing class became 35 and 75 after joining the hypnobirthing classes.

\section{Normality Test}

The results of data normality test by using the Kolmogorov Smirnov method showed that the probability score (p) in the subject who got hypnobirthing class was 0.200 for the pre-test score and the post-test score was 0.001, which mean that the data was not normally distributed. The result of the data normality by using the Kolmogorov Smirnov method showed that the probability score (p) in the control group subject was 0.200 and the post test score was 0.011 which also mean that the data was not normally distributed. It was because the data was not normally distributed, and the analysis test was using the non-parametric tests with Mann Whitney test.

Table 1. The results of the difference test between mean and median of the anxiety level with Mann Whitney after hypnobirthing classes.

\begin{tabular}{lccccc}
\hline \multicolumn{1}{c}{ Group } & n & Mean & Median & Mann Whitney & p \\
\hline Hypnobirthing & 15 & 41.33 & 36.00 & \multirow{2}{*}{41.000} & \multirow{2}{*}{0.003} \\
Non-hypnobirthing & 15 & 51.60 & 48.00 & \\
\hline
\end{tabular}

\section{DISCUSSIONS}

Based on the result of analysis by using Mann Whitney, it showed that the data was normally distributed with the score of $\mathrm{p}=0.003$, this score was smaller than $\alpha=$ 0.05, which mean that there was a difference in the average level of anxiety after joining a hypno-birthing class in which the level of anxiety decreased than the score before joining the hypnobirthing class.

The data showed that the average of anxiety score before joining the hypnobirthing class was 55.80 to 41.33 after joining the hypnobirthing class. This showed that there was an effect of hypnobirthing classes in reducing anxiety 
levels in primigravida and multigravida pregnant women in facing the delivery.

Basic techniques of hypnobirthing including relaxation and affirmation, visualization, communication with the fetus, and deepening could help the pregnant women to control their body and soul or mind harmoniously during pregnancy to prepare themselves for delivery. Thus, there was a sense of calm and confidence that the body would be able to function naturally in the process of delivery. After learning to enter the deep relaxation conditions, pregnant women would be able to neutralize negative recordings in their subconscious and replaced them with positive programs. (O’neill, 2002).

Hypnosis was the condition of relaxed, focused, calm, positive perceptions, and covered all aspects of life. First, the hypnotized person can absorb what was suggested to him/her and was not affected by the atmosphere around him/her. Second, hypnosis was how someone can act for what she/he was suggested. For example, the therapist suggested someone to forget or slowly erase the incidence of trauma. There are 7 steps of hypnosis, among others: (1) preparation/pre-induction was hypnosis apperception, motivation to client, confirmation of keywords, informed consent; (2) relaxation and induction were attempts to take clients into hypnosis condition; (3) isolation was protecting the clients from outside influences that could interfere the hypnosis process; (4) The test was a method of knowing whether the client has entered the hypnosis or not; (5) consolidation was bringing the client into a more hypnotized phase; (6) implantation was to impose the suggestions and affirmations as agreed; (7) termination was the phase where the hypnosis would be resolved or the client would be awakened.
The effect of hypnobirthing on pregnant women in this study was said to be quite successful in reducing the level of anxiety in facing the delivery. Hypnobirthing taught pregnant women to integrate with the natural rhythm of the body in doing the delivery process, it allowed the body to function as it should be so that the mothers did not feel the pain (Mongan, 1995).

The general benefits of hypnobirthing for mothers including: (1) Natural ways to reduce pain and complaints during pregnancy and delivery; (2) Reducing nausea, vomiting, and dizziness in the first trimester; (3) Did not have side effects on the baby; (4) Reducing stress; (5) Making mothers more calm and psychologically prepared; (6) Eliminating fear, tension, and anxiety; (7) Reducing the risk of complications; (8) Assisting the position of the fetus which was breech, latitude, or umbilical cord to normal position; (9) Increasing the mother's inner bond to the baby and husband; (10) Mother can communicate with the infants in the womb; (11) The recovery period for post-labor was more comfortable; (12) Accelerating breast milk production.

The benefits before delivery for the mothers were: (1) Reducing anxiety and fear before delivery which can cause tension, pain, and pain during delivery; (2) Helping the mothers to feel comfortable, relaxed, and safe before delivery; (3) Helping the mothers to able to control the sensation of pain during uterine contractions; (4) Reducing anesthetic needs; (5) Reducing fatigue and saving energy greatly during the labor; (6) Streamlining the delivery process; (7) Increasing the levels of endorphins in the body to reduce pain during contractions and accelerating the delivery. From the results of this study, it can be concluded that Hypnobirthing was 
effective in reducing anxiety levels in facing the delivery with the score of $\mathrm{p}=0.003$. The average of anxiety level of pregnant women who got hypnobirthing classes was lower than those who did not join the hypnobirthing classes (hypnobirthing mean $=41.33 ; \mathrm{SD}=12.216 ; \mathrm{p}=0.003$; nonhypnobirthing mean $=51.60 ; \mathrm{SD}=10.60$ ).

\section{REFERENCES}

Aprillia Y (2010). Hipnostetri. Jakarta: Gagas Media.

Brown D, Food (2001). Women's Evaluation of Intrapartum Non pharmakological Pain Relief Method Used During Labor. The Journal of Perinatal Education (10) 3. Cyna (2004). Hypnosis For Pain Relief In Labour and Childbirth: A Systematic Review, British Journal of Anaesthesia (9): 505-511.

Fiori J (2005). Pregnancy Fitness, Panduan Kebugaran Selama Hamil. Jakarta: Prestasi Pustaka.

Madden K, Middleton P, Cyna AM, Matthewson M, Jones L (2012). Hypnosis for pain management during labour and childbirth. Cochrane Database Syst Rev.

Hurlock EB (1997). Psikologi Perkembangan: Suatu Pendekatan Sepanjang Rentang Kehidupan (Ed. 5). Jakarta: Erlangga.

Misri S, Kendrick K, Oberlander TF, Norris F, Tomforh L, Zhang H, Grunau RE (2010). Antenatal Depression and Anxiety Affect Postpartum Parenting stress: Longitudinal, prospective. Can J Psychiatry 55 (4): 22-28.

Murti B (2010). Desain dan Ukuran Sampel untuk Penelitian Kuantitatif dan Kualitatif di Bidang Kesehatan. Yogyakarta: Gadjah Mada University Press.

O’Neil ML (2002). Better Birthing with Hypnosis. New York: Mc Graw- Hill Two Penn Plaza.

Mongan M (1995). Hypnobirthing. USA: Health communication.

Varney (2007). Buku Ajar Ilmu Kebidanan. Jakarta: EGC. 